Subglobular, lateral gall with dead area on one side, diameter $9 \mathrm{~mm}$. Rhabdophaga globosa Felt. Irregular, ovoid or subglobular galls, diameter 1 to $2 \mathrm{~cm}$.

Rhabdophaga batatas Walsh. Same gall as above...............Rhabdophaga ramuscula Felt. Same gall dried...................Asynapta saliciperda Felt. Subglobose galls, the surface scarred, diameter $4 \mathrm{~mm}$.

Mayetiola tumidosa Felt.

\title{
SOME NEW SPECIES OF WEEVILS OF ECONOMIC IMPORTANCE
}

\section{By W. Dwight PIERce, U. S. Bureau of Entomology, Dallas, Texas}

I beg the indulgence of $\mathrm{my}$ colleagues for combining in a single article purely taxonomic matter with a discussion of biologic and economic subjects. My plea is that the course I follow shows in a rather striking manner the close interrelationship between the economic and systematic branches of our science.

In a recent publication on the "Parsley Stalk Weevil (Listronotus latiusculus Boh.)," Dr. F. H. Chittenden cites examples of serious damage done by the semi-aquatic weevils Listronotus appendiculatus Boheman and Notaris puncticollis LeConte to cabbage in Ohio, and by Listronotus latiusculus Boheman to parsley in Virginia. He cites in addition, the tendency of the genus Sphenophorus to attack com (Bur. Ent., bul. 82, part II, p. 14). These are all examples of the results of planting crops on newly drained land, when weevils which normally inhabit marshes have depredated on cultivated crops.

This brief notice describes a phenomenon in the biologies of weevils which is by no means uncommon, although perhaps not well understood as yet. ${ }^{1}$ There are among our American weevils several very sharply defined groups of forms without wings or with rudiments of wings only. The classification of LeConte and Horn overlooks this important character and by raising other characters to primary im. portance has obscured it and dissociated what appear to the writer to be nearly related forms. The majority of these wingless weevils pass their developmental period in the ground at the roots of plants. Whenever it happens that land is cleared, and the plants eliminated have been the hosts of multitudes of these weevils, it is almost certain

\footnotetext{
${ }^{1}$ This paper deals only with weevils, however workers in other groups will recognize the existence of the same phenomenon.
} 
that the planted crops will suffer from weevil depredations. In some cases it is probable that the life cycle of these weevils is more than one year and hence it may not seem apparent that clearing the land is responsible. If the plants attacked are trees or shrubs, these weevils may be easily handled by banding with some sticky substance.

As shown by the examples given and others in the literature of economic entomology the draining of marshes, or clearing of timber, or breaking up of meadows, or even the clearing off of under-brush have given rise to weevil inroads upon cultivated crops. Moreover such instances with winged as well as wingless species will be of frequent recurrence. Mr. Fred E. Brools has recently written me of serious depredations of Anthonomus scutellatus Gyllenhal, upon grape blossoms in West Virginia, adding that from the grapes the weevils went to the rose bushes nearby. Dr. Chittenden's examples show the results of draining marsh lands. The breaking up of a lupine meadow infested by a species of Sitones and planting of a leguminous forage crop would without a doubt give rise to an attack from this weevil.

Even rotation of certain crops is dangerous. When Chalcodermus ceneus Boheman, has been very injurious to cow-peas it is inadvisable to plant cotton, for the weevils will invariably depredate upon the cotton foliage and Dr. W. E. Hinds has demonstrated that they can breed successfully in a cotton square.

Still another important phase of the general problem we are discussing is the introduction of a cultivated crop into the vicinity of wild plants which are nearly related. If these wild plants have important enemies and the new crop encroaches upon them or directly or indirectly causes their eradication, the insect enemies are likely to find the cultivated crop a better medium for propagation than the variable wild plants. Bearing this point in mind it is not proper to plant cabbages, turnips, mustard or other crucifers on ground just cleared of an abundant wild crucifer. An example of what will happen is cited in the description of a new species of Ceutorhynchus given herewith. A similar example is the danger of planting apple, quince or pear orchards in the vicinity of a grove containing haw-trees (Cratcegus sp.). Mr. Fred E. Brooks has just published an article on the insects of the apple in West Virginia in which he cites Tachypterellus (Anthonomus) quadrigibbus Say and Pseudanthonomus cratcegi Walsh as important apple enemies. Both of these weevils and the quince weevil (Conotrachelus cratogi Walsh) are native to Crategus. In this connection I should expect the advent of apples into Louisiana or South Texas to bring about the change of 
Anthonomus nebulosus LeConte, and Anthonomus pallidus Dietz, both bud weevils, from Cratregus to the apple. The proximity of grape vineyards to woodlands containing woodbine and wild grape undoubtedly gave rise to the two grape pests Ampeloglypter sesostris LeConte, and A. ater LeConte. These examples might be multiplied many times, and I expect to cite all such cases in a list of the breeding labits of North American weevils now in preparation.

The recent discovery of several new species of weevils which have come into view as destructive to important crops is the reason for the present article. Four of these weevils have been transmitted by State Officials and it is due to them that descriptions be published so that they may use the notes in their reports. The proper elucidation of two of these weevils has necessitated a preliminary statement of a revised classification of our North American weevils. As many months of work is still necessary to the completion of this classification I can but indicate the direction it will take.

It has become necessary in the writer's opinion to drop the LeConte and Horn conception of the classification of the Otiorhynchida and to return to Lacordaire, accepting the modifications proposed by Stierlin, Sharp and other recent authors. It will be sufficient in the present article to limit the subfamily Brachyderina, which is almost the equiv. alent of Stierlin's Brachyderini, to those weevils with linear scrobes, directed beneath, contiguous anterior coxæ and prothorax without vibrisse. The subfamily Otiorhynchinæe is the equivalent of Stierlin's Otiorhynchini and includes those weevils which have the scrobes variable, never at the same time, linear and directed beneath. By this system all of the wingless weevils with unequal abdominal segments, scaly antenne and underparts, and with simple claws are grouped together in the Epicærini. The result is a group of weevils of similar appearance and with like biologies. Hence the economic treatment becomes much simplified for we find that a few definite rules can be laid down for the treatment of the whole tribe.

\section{FAMILX OTIORHYNCHID $邓$}

\section{SUbFamILY BrachyderinaE}

\section{Tribe Epiccerini}

I. Side-pieces of mesosternum very unequal, the episternum larger and attain. ing the elytral margin, epimeron usually small, sometimes very small

a. Articular face of hind tibiæ glabrous, support of decituous piece modk erately prominent. 
b. Antennæ stout, last joint of funicle short, broad and very close to club, first two joints of tarsi glabrous....... Graphorhinus Schönherr

bb. Antennæ more slender, joints of funicle conical, the last distant from the club; tarsi pubescent..................Epicarus Schönherr

aq. Articular face of hind tibiæ scaly; support of deciduous piece very prominent; antenuæ rather slender, club distinct....Anomadus Horn

II. Side-pieces of mesosternum diagonally divided and equal or very nearly so, episternum distant from the elytral margin, separated by the epi-

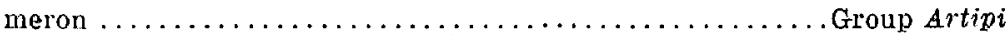

c. Tenth elytral striæ entire.

d. Genæ feebly emarginate; anterior tibiæ not denticulate within but with a row of sharp spines; second segment of abdomen not longer than the two following.................... Omileus Horn

dd. Genæ strongly emarginate; anteriar tibiæ denticulate within; second segment of abdomen usually as long or longer than the two following.

e. Tips of hind tibiæ with, at most, a double row of fimbriæ.

f. Second joint of funicle elongate, longer than first Aramigus Horn

ff. Second joint of funicle shorter than first...... Lepidocricus n. g. ee. Tips of hind tibir with oval scaly space; second joint of funicle elongate, longer than first............... Phacepholis Horn cc. Tenth elytral striæ confluent with the ninth; second segment of abdomen longer than the two following; genæ strongly emarginate.

Artipus Schönherr

\section{Graphorhinus Schönherr}

Graphorhinus vadosus Say is the only representative of this genus. It has been taken feeding on clover leaves.

\section{Epiccerus Schöpherx}

The genus Epicarus presents considerable difficulty in its study on account of the great variation in color pattern and the sexual differences. It seems probable that the many references of injury to economic plants charged against Epiccerus imbricatus Say are applicable to a number of different species.

In general the females are characterized by the more inflated abdomen, the thorax broadest at base and the apical declivity generally concave. The males have the body more cylindrical, the elytra not inflated, the thorax broadest at middle and the apical declivity straight or convex, seldom shallowly concave. It is therefore erroneous to base a table of differentiation of species upon the widest part of the thorax.

\section{Table of Species}

A. Frontal fovea round; beak not sulcate and seldom even shallowly depressed on median line, not deusely clothed with scales.

я. Frontal fovea small; beak medianly shallowly depressed; pronotal punctuation very fine, with few large depressions, median line broadly 
depressed; elytral strial punctures large and irregular; scales rusty .................................mexicanus Sharp

ar. Frontal fovea large or moderate; beak sometimes medianly shallowly depressed; pronotal punctuation fine with many large foveate depressions, median line depressed; strial punctures regularly arranged; scales variable in color; scales of bealk densest in lateral depressions, sparse along median line............ imbricatus Say

B. Frontal fovea more or less elongate; beak more or less sharply sulcate on median line, densely clothed with scales.

b. Sixth funicular joint longer than wide, seventh longer than sixth; vestiture of scape not scaly at apex; elytra almost twice as long as wide; prothorax medianly sulcate....................texanus Casey

bb. Sixth funicular joint hardly longer than wide; elytra short; vestiture of scape scaly at apex.

c. Elytra from one-half to two-thirds longer than wide.

d. Seventh funicular evidently longer than sixth; median line of pro. thorax sulcate; length $\delta-10 \mathrm{~mm} . . . \ldots \ldots \ldots \ldots$.............. Casey

dd. Seventh funicular hardly if any longer than sixth; median line hardly indicated; elytra about $1 / 2$ longer than wide; length $4.5-$ $6.5 \mathrm{~mm} . \ldots \ldots \ldots \ldots \ldots \ldots \ldots \ldots \ldots \ldots \ldots$ lepiantus $\mathrm{n} . \mathrm{sp}$.

cc. Elytra but slightly longer than wide........ formidolosus Boheman

(Epiccerus lucanus Horn belongs in b.)

Epiccerus mexicanus Sharp is a Mexican species extending into Texas at Brownsville.

Epiccerus imbricatus Say is a Northern species occurring as far south as Arkansas, Oklahoma and North Texas to Dallas and Gurley. It is charged in the literature with serious depredations on apple, bean, beet, blackberry, cabbage, cherry, clover, corm, cotton, cucumber, gooseberry, muskmelon, onion, peach, pear, plum, potato, radish, raspberry, strawberry, squash, tomato and watermelon. Very possibly some of the other species of the genus were responsible for part of these records.

Epicarus texanus Casey is a Southwestern species occurring in the chaparral country of Texas. It has no serious charges against it as yet.

Epiccerns lucanus Horn is a very large weevil recorded only from Lower California.

Epicarus sulcatus Casey is also Southwestern, probably coinciding in range with $E$. texanus.

Epicarus lepidotus n. sp.

Length $4.5-6.0 \mathrm{~mm}$. Form oval, not very robust, sometimes quite slender, densely clothed with small round, lineolate, iridescent white to pale brown scales arranged in definite patterns. Beak very little longer than head, about as wide as long, broadly convex separated from flatter front by very slight transverse depression; tip of beak angularly emarginate, with a median 
smooth space surrounded by a broadly ogival raised margin; median impressed line deep extending to interocular fovea; lateral impressions short, feeble; surface coarsely punctured at tip, remainder of beak closely squamose, with whitish scales and with sparse setigerous punctures; antennæ with scape scaly at tip; seventh funicular hardly if any longer than sixth. Prothorax wider than long; in shape varying for the sexes as in other species; apex and base truncate; disk convex, nearly even, with a very faintly indicated median line; surface densely squamose, with sparsely alranged setæ, the median line indicated by a slender vitta of ochreous brown scales on a broad white median vitta, at each side of this is a light brown vitta and a smaller one on the sides, the remainder of the surface is pale. Elytra oval, usually widest about the middle, never more than one-half wider than prothorax, about one-half longer than wide; striæ consisting of small distant punctures, very feebly depressed; intervals flat; surface closely squamose, with interspersed dark setæ, scales darker above, and pale on the inflexed sides, with four small basal spots, two irregular transverse vittæ and apex also pale; legs and under-side squamose, finely and sparsely clad with pale setæ.

Described from eight specimens collected by E. A. Schwarz at San Antonio, Texas, May 9 and 10 . It is also at hand from Cotulla and Brownsville, Texas. Types in U. S. N. M. No. 13122.

Epicarus formidolosus Boh. is known only from Florida

\section{Anomadus Horn}

Anomadus obliquus Horn is from the Peninsula of Lower California. I have seen no records of its habits.

\section{Omileus Horn}

Omileus epicceroides Horn is a large and common east Texas species. In March, 1904, the fruit growers of eastern Texas suffered considerable damage to the foliage of peach trees from an outbreak of this species. Professor E. D. Sanderson found that it was normally an oak insect and that the greatest damege was to newly planted orchards on land just cleared off and surrounded by oak (Ent. News, vol. XVII, p. 210).

\section{Aramigus Horm}

Aramigus fulleri Horn is a very widely distributed and exceedingly injurious species. It breeds at the roots of plants and is recorded as a serious enemy of apple, blackberry, peach, plum, sugar-cane and strawberry. It attacks many economic plants of Hawaii. Mr. D. L. Van Dine recommends treatment that will be applicable to most of these weevils. When they are found breeding at the roots of plants, the use of carbon bisulphide in the soil or fertilizing with tobacco waste is recommended. From trees and shrubs the weevils may be ex- 
cluded by wrapping with cotton bands. When on the plants spraying with arsenate of lead is recommended.

Aramigus tessellatus Say has been recorded as injurious to sweet potatoes.

\section{Lepidocricus $\mathbf{n} . ' \mathrm{~g}$.}

Rostrum not longer than head, separated from head beneath by very sharp and deep constriction; genæ strongly emarginate; antennæ short, first joint of funicle longer than second, remaining joints moniliform; scales of thorax dull, arranged in circles upon the numerous approximate tubercles; strial punctures of elytra round but appearing linear because of closer scaly vestiture, each bearing a tiny seta; anterior tibiæ strongly denticulate within; tips of hind tibiæ with only a single row of fimbriæ apparent; second segment of abdomen considerably longer than the two following, with first suture angulate.

Name derived from $\lambda \epsilon \pi i s$, scale + кpíкs, a circle, signifying a circle of scales with reference to the vestiture of the thorax. The type of the genus is $L$. herricki $\mathrm{n}$. sp.

\section{Lepidocricus herricki n. sp.}

Form robust, oval, surface densely covered with grayish to brownish concave lineolately sculptured scales, with no striking color pattern. Head and rostrum about as long as thorax, medianly deeply canaliculate, surface longitudinally rugosely punctate, covered with cinereous scales and bristles, at tip, nearly naked. Prothorax broader than long, apex slightly narrower than base, sides very strongly convex, median line not indicated, surface closely covered with cylindrical tubercles, each with a deep bristle bearing puncture, thus resembling craters, the scales arranged upon these tubercles in circles, on some specimens forming a lighter band on each side of the median line, and with sides lighter. Elytra oval, about two and a half times as long as prothorax, striate, striæ with moderately close, coarse setigerous punctures which are always obscured and appear linear in a fully clothed. specimen, intervals almost flat, each with a row of short bristles, surface densely covered with concave lineolately sculptured round to ogival scales. Body beneath sparsely clothed with small thin scales, but more densely with long white setæ; third and fourth abdominal segments strongly depressed. Legs densely scaly, and pubescent. Length $5-6 \mathrm{~mm}$.

Described from five specimens loaned me by Professors Glenn W. Herrick and R. W. Harned; collected by a correspondent (J. B. Easter) at Easter in Monroe Co., Miss., May 7, 1904. Types in the U. S. N. M. (No. 13084) and also in the collection of Mississippi Agricultural College.

Professor Herrick writes that his correspondent said that these "weevils had made their appearance on his farm and were feeding on his young cotton, saying, "it looks as though they were going to destroy the whole stand. It is something new in this section of the country. 
They eat the leaves off the cotton and even eat it before it gets out of the ground.' Evidently the beetles were so destructive that the cotton had to be replanted, for on May 25, he writes again as follows: 'I would have written you before but was waiting to see what the insects would do to our second planting. The cotton is now up and I don't see any sign of them yet.'

"Nothing more was ever heard regarding the beetles and they probably did not again appear in numbers sufficient to attract attention. The outbreak is interesting however, especially since the species has shown an ability and an inclination to become a serious pest and might easily appear again over a larger area."

\section{Phacepholis Horn \\ Table of Species}

1. Beak deeply and angulately emarginate at apex; only the anterior tibiæ denticulate within.

a. Antennæ elongate; funicular joints elongate, the second much longer than the first and considerably longer than the two following. Prothorax squarely truucate, wider than long; vestiture brilliant metallic green to bluish green above...................elegans Horn

aa. Antennæ not so elongate, funicular joints elongate, the second very slightly longer than first if at all, and subequal to the two following; protholax slightly obliquely truncate, slightly wider than long; vestiture white to grayish green.................. pallida $\mathrm{n}$. sp.

2. Beak emarginate at apex but not deeply so; antennal funicular joints elongate, the second subequal to the first or but slightly longer; prothorax obliquely truncate; anterior and midlde tibiæ denticulate within.

b. Elongate; anterior tibiæ internally strongly serrulate dentate; second abdominal segment a little shorter than the next two combined; vestiture white to light ochreous.......................

bb. Stout; anterior tibiæ with a very few isolated elongate teeth; second abdominal segment longer than the two following; vestiture

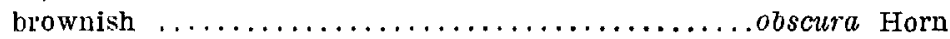

Phacepholis elegans Horn. I have specimens which seem in every way typical from San Antonio, Victoria, Kerrville, Edna and Cotulla, Texas, all southwestern points in the chaparral country. Specimens were taken on cotton at Victoria and San Antonio.

Phacepholis pallida n. sp.

Length 4.5-6 mm. Body oval, robust, black but densely clothed with irdescent white to light green scales, and slight erect setæ, the general appearance being gray to. grayish green. Head and rostrum nearly as long as the tholux; head not or very feebly constricted behind the eyes; densely covered with rounded, striate white to iridescent pink scales and upright, elongate, apically truncate, striate white scales; beak apically deeply emarginate; 
median line deep and distinct to base of head; eyes very convex, moderately prominent. Antennæ not as elongate as in elegans, but with all funicular joints longer than wide, the second very slightly, if at all, longer than first, and subequal to the two following. Prothorax slightly wider than long, slightly obliquely truncate at apex, sides arcuate; disk moderately convex, moderately coarsely punctured; densely covered with the two kinds of scales described for the head. Elytra oval, sides feebly arcuate, surface striate, strial punctures moderate, not closely placed, intervals flat, densely clothed with both kinds of scales. Body beneath more sparsely clothed as above, in greenish specimens the under-sides are clothed with white; anterior tibix with strong elongate teeth; median tibiæ internally slightly roughened serrulate.

Described from five specimens collected at Corpus Christi, Texas, May 17, 1905, by A. C. Morgan on cotton. Also found at Victoria, Texas, on cotton. Type Cat. No. 13123 U: S. N. M.

Phacepholis candida Horn is known from Colorado and Kansas.

Phacepholis obscura Horn. On March 22, 1910, Professor Wilmon Newell of Texas received from R. E. Williams at Mineral Wells, Texas, a large number of these weevils with the following remarks:

"I am sending you today some bugs which have almost eaten up our spinach. They eat on plant, and at night or when cool they will be found under the dirt, find from 2 to 12 bugs under one plant."

This record places the genus Phacepholis in the same category as the other economic genera and indicates that the occurrence of these species on cotton may also be of importance.

\section{Artipus Schönherr}

Artipus floridanus Horn. This species is found commonly on Baccharis halimifolia and Borrichia frutescens in Florida but numerous authors have recorded serious injuries to the blossoms, young fruit, and leaves of citrus trees, especially limes, in Florida.

It seems probable that the recommendations of $\mathrm{Mr}$. Van Dine for the control of Aramigus fulleri will be applicable to all insects of the tribe Epicarini which has been treated in its entirety for our North American fauna on the preceding pages.

\section{SUbFamily OTtorhynchinaE}

\section{Tribe Trachyphlogini}

\section{Cercopeus Schönherr}

The tribe to which this genus belongs has been limited in our North American fauna to four monotypic genera and it is therefore with considerable pleasure that $\mathrm{I}$ am permitted through the courtesy of Pro- 
fessor R. A. Cooley and Mr. E. A. Schwarz to describe a second species in one of these genera.

\section{Table of Species}

Scales luteous to brown, with darker discal spot on elytra; length 3-5

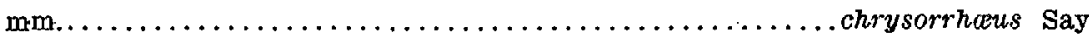

Scales iridescent white to shining ochreous, slightly mottled on elytra but not forming a distinct spot; length $3-3.5 \mathrm{~mm} . \ldots \ldots \ldots \ldots \ldots$ artemisia $\mathrm{n}$. sp.

\section{Cercopeus artemisice $\mathrm{n}$. sp.}

Size 3-3.5 mm. Color black to piceous, densely covered above and below with round, slightly overlapping, white or ochreous, flnely striulate, appressed scales, which are intermixed with long, fine, white setæ; elytral intervals uniseriately setigerous. Beak slightly longer and narrower than head, clothed with scales to tip, with a smaller interocular fovea, and a median line toward apex; scrobes superior, deep in front, shallow behind, not reaching eyes by a distance subequal to their own length. Antenna rufous; scape reaching thorax, scaly and pubescent; club about equal to the last four funlcular jolnts. Eyes rounded, moderately convex; ommatidia relatively large, separately convex, giving the appearance of a flattened raspberry. Thorax transverse, basally and apically truncate, laterally broadny arcuate. Elytra not one half longer than wide; humeri obliquely rounded; striæ as seen with scaly vestiture complete, very fine but sharp; intervals clothed with from three to five rows of closely placed pavement scales, but uniseriately setigerous. Under-sides densely scaly; front coxæ contiguous; middle coxæ very narrowly separated; intercoxal process truncate and transversely impressed before apex. Second abdominal segment about equal to two following, fifth longer. Femora and tibiæ densely scaly; anterior and median tibiæ strongly mucronate; tarsal claws strongly divergent.

Described from nine specimens collected by R. A. Cooley at Corvallis, Montana, May, 1909, injuring cherry trees, but evidently native to Artemisia tridentata. Prof. Cooley writes that the "species was reported doing considerable damage over large tracts of newly planted orchards. It was particularly injurious on cherry trees. I examined the trees and traced the beetle to a species of Artemisia tridentata I think. I I believe the species feeds normally and breeds on this plant. I accounted for its presence in the orchards by the fact that its normal food plant was cleared off, leaving little else for the beetle to eat other than the fruit trees." Type Cat. No. 13083 U. S. N. M.

\section{Family CURCULIONIDA}

\section{Subfamily Ceutorhynchinae.}

\section{Ceutorhynchus Germar}

The following species belongs in the true Ceutorhynchus, with 7jointed antennæ, and in Dietz's "squamatus group." The first section of that group can be distinguished as follows: 
1. Above shining, finely pubescent with scattered larger scales.

a. Elytra without rows of acute granules.

b. Scutellar spot of elongate whitish scales........anthonomoides Dietz bb. Scutellar spot and transverse fascia behind the middle of the elytra of large white oval scales.................squamatus LeConte

aa. Elytra with rows of acute granules; third joint of tarsi broadly bilobed; thorax with median antebasal and postapical depressions, the former clothed with elongate white scales; scutellar region not clothed with white scales ............................ lesquerelloe n. sp.

2. Above densely scaly or coarsely pubescent.

Ceutorhynchus lesquerella $\mathrm{n}$. sp.

Length $2 \mathrm{~mm}$. Oval elliptic, black throughout, clothed with extremely fine inconspicuous pubescence above and with rather sparse elongate scales, densest on thorax, below. Beals moderately slender, regularly and rather strongly curved, cylindrical, minutely pubescent to middle, striate and punctured from the base to the insertion of the antennæ, more remotely puncted toward the apex. Head flattened, rather coarsely punctured. Prothorax about one-half wider than long, almost twice as wide at base as at apex, convergently rounded on the sides, strongly constricted at apex, ocular lobes distinct, lateral tubercles small, acute, disk with deep antebasal and postapical impressions, the former bearing the only spot of condensed scaly vestiture visible from above; disk uniformly, closely and coarsely punctured; scutellum invisible. Elytra a little wider at base than prothorax; humeri obliquely rounded, striæ impressed but very confusedly punctured; interspaces very little wider, convex, each with a row of acute granules which become longer and tuberculfform towards the declivity. Under-side densely and coarsely punctured, mesosternum and side-pieces densely, the rest of surface less densely clothed with large, elongate scalos, smaller on the abdomen. Femora arcuate; tibiæ a little widened towards apex; tarsi moderate, first and second joints elongate, third broadly bilobed, fourth joint projecting about the length of the third.

Types in U. S. National Museum No. 13085.

Described from four specimens received March 22, 1909, from Prof. Glenn W. Herrick, then State Entomologist of Texas, who reported them to be destroying cabbage plants as fast as they came up in seed beds at Whitewright, Texas. Two specimens of this species were collected April 18, 1906, at Wolfe City, Texas, by F. C. Bishopp. On April 3, 1909, Mr. E. S. Tucker found the weevil breeding abundantly in the crown of the crucifer, Lesquerella gracilis at Plano, Texas.

It is safe to assume that of the several new species herewith described this is the most dangerous and it will be looked for with in. terest this year.

I take occasion at this time to state that I have in preparation a complete revision of my former list of the breeding habits of North American weevils. Any assistance will be very gratefully acknowledged. 